\title{
DIGITAL MODELS FOR THE ANALYSIS AND ENHANCEMENT OF HYBRID SPACES: ARCHITECTURE OF THE MATTANZA
}

\author{
L. Repola ${ }^{1, *}$, J. Leidwanger ${ }^{2}$, E. S. Greene ${ }^{3}$ \\ ${ }^{1}$ Department of Humanities, Suor Orsola Benincasa University, via Suor Orsola 10, \\ Napoli 80135, Italy - repolaleopoldo@ gmail.com \\ ${ }^{2}$ Department of Classics, Stanford University, 450 Jane Stanford Way, Stanford, California 94305, USA - jleidwa@ stanford.edu \\ ${ }^{3}$ Department of Classics, Brock University, 1812 Sir Isaac Brock Way, St Catharines, \\ Ontario, L2S3A1, Canada - egreene@brocku.ca
}

Commission II - WG II/8

KEY WORDS: Digitization, Exhibition, Archaeology, Tuna fishing, Maritime history, Underwater cultural heritage

\begin{abstract}
:
Project ' $U$ Mari examines the long-term relationship between the sea, coast, and local peoples through the various lenses of maritime mobilities, interactions, and livelihoods along the shore of southeast Sicily, specifically between the Vendicari Reserve and Capo Passero. With an eye toward valorizing the 'mattanza' as intangible cultural heritage, our work focuses on the rich material remains of this distinctive Mediterranean form of bluefin tuna trap fishing, using 3D recording and visualization of its associated objects, spaces, and landscapes to relate vivid diachronic stories for the public. Our methodology integrates archaeological survey of the landscape, architecture, and social practices of tuna fishing that act as a bridge between ancient, early modern, and contemporary livelihoods. Through comprehensive digitization, we generate interoperable and parametric models aimed not only at the recording and restoration of objects and spaces, but also - in combination with interviews and archival work - at the valorization and revitalization of traditional practice within contemporary socioeconomic contexts. Through these digital methods, Project 'U Mari seeks to engage the public with a deeper understanding of historical maritime lifeways using exhibition, virtual environments, and revived traditions. Such an approach can encourage environmentally sound fishing practices that draw on local knowledge and yield local economic benefits and responsible tourism. In this way, the historic and archaeological past offers the opportunity to create a new common language for understanding and communicating the architectural evidence of local traditions, history, and livelihoods in this rich maritime landscape.
\end{abstract}

\section{INTRODUCTION}

Diverse places that bring together knowledge related to the life of the sea, the 'tonnare'-or tuna-fishing and processing installations - of southeast Sicily offer many paths toward understanding the human past. Through its long historical trajectory, its characteristic techniques and spaces, and its durable social structures, fixed-net tuna fishing - specifically the communal process of the 'mattanza' - offers a window into the close connections between people, the land, and the sea. By their very nature, the mattanza and tonnare extend beyond the economic and even the social and ecological, into the worlds of ritual and narrative, where the bloody slaughter recalls a sacrifice that reflects the ongoing struggle between fishing practitioners, tuna, and the marine environment.

Such themes lend themselves to a multiplicity of approaches and allow the development of different lines of research into the architectural plans and archaeological remains of physical structures related to the tonnare and mattanza. Studies of tonnare comprise a wide range of diverse facets: economic (production, processing, trade and consumption of fish), ethnoanthropological (inventories, tools, diaries of 'raisi'- the captains of the tuna fleet - and administrators, and for the 20th century, photographic, video and audio documentation), socioreligious (traditions and ritual nature of the mattanza), legal (fishing concessions, rights, regulations, disputes among and within communities), architectural (standing and ruined remains), as well as archaeological and marine biological both on- and offshore. If, on the one hand, tuna fishing bears witness to the progressive variation of territorial management by different authorities within evolving socio-economic contexts and legal-administrative frameworks, on the other hand it highlights a continuous developmental lineage of the maritime past as a symbiotic relationship between humans and nature. Through a multifaceted approach that combines landscape survey, archaeological and ethnographic recording, and digital representation, the project explores the vernacular architecture of tuna fishing in southeast Sicily as a path toward valorization of the complex and varied heritage of this uniquely local maritime tradition.

\section{MATERIAL CULTURE OF THE MATTANZA}

The most visible remains of the mattanza, tonnare comprise a vibrant and valuable part of Mediterranean cultural heritage, offering insight into tangible practice and intangible knowledge systems and lifeways. Their extensive material remains range from archaeological ruins of millennia of fishing and fishprocessing to standing industrial heritage and vessels of the early modern and recent fleets. Spanning the dry land of shore, recently submerged landscapes, net anchors, shipwrecks, and other underwater cultural heritage, as well as the embedded structures and traditions of local communities, this dataset presents an exciting new challenge to data management, scientific analysis, and public presentation. Archaeological approaches to the landscape of fishing are critical to the collection of data. Through remote sensing we can understand

\footnotetext{
* Corresponding author
} 
the topography of the underwater environment and how specific landscapes drive the creation of structures on land and in the sea. Ground-truthing the remote sensing data through systematic diving survey should allow reconstruction of the underwater landscape of the mattanza and its associated structures of complex built nets and anchors. Preserved vessels associated with particular fishing communities reveal local adaptations to traditional craft. Finally, recording of the architecture of the multiple tonnare structures on land reflects the viewsheds and work systems through which communities were connected to the tradition that drove their economic, social, and ritual worlds.

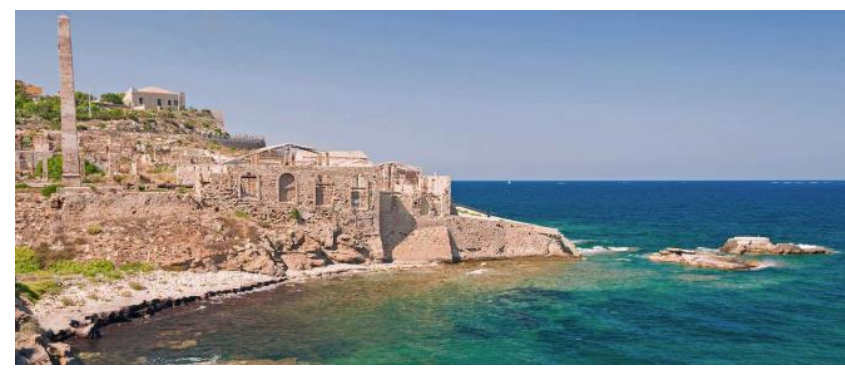

Figure 1. The tonnara of Portopalo.

\subsection{Structures of net, wood, and stone}

The architectural complexity of the mattanza is encapsulated by the 'madraga' or net structure. The physical net serves also as a metaphor for the meshwork that joins land and sea, human and fish, economy, culture, and nature. These knotted webs of rope and fiber reflect the multiple practices of tuna fishing. Purse-seine fishing in enclosed bays, 'tonnare di golfo', involved mobile nets and fast boats. In some cases, especially in antiquity, this operation was commanded by a 'thynnoskopos '- a fisherman who directed the crews and nets around the catch by sight from an elevated observation point on land ('specola' or 'thynnoskopeion'). More consolidated and organized systems involved fish catching and processing plants located on promontories or islands, known as 'tonnare di punta'. In these operations, a complex system of fixed nets was laid out from a point on the coast, in expectation of the migrating tuna. Offshore fishing techniques ('tonnare volante') are not discussed here, primarily because their evidence is poorly preserved archaeologically and did not require the same group coordination that created this uniquely complex and dynamic architecture of fishing.

The architecture of the 'tonnare fisse' (fixed tonnara) links the spaces of tuna fishing on land and in the water. This structure spans the two environments, adapting to the laws of the sea and shore with its materials of net, wood, and stone. The architecture requires many specific features. It must stretch out into the sea to access the currents and migratory routes of tuna; it requires the shelter of a bay to accommodate the boats as well as sea salt for packing from nearby lagoons. It must offer smooth low slopes for pulling wooden hulls ashore, rocky features for tying the net's lead and also an offshore seabed without rocks where the net structure can be set on the sand and made to swell as the currents pass. Sensorial accompaniments to this tangible architecture include the air carrying the scent of blood, fish, and fatigue across the wine-dark sea; the shanties of fishermen at their oars and the lapping waves they cross; and the bright flashes emitted by the thrashing bodies of the 'pesce di luce' 1 .

\footnotetext{
1 Pesce di luce is the description given to the tuna by the rais Luigi Marina and the tonnarota Emilio Gregori during the extended interviews conducted in the summer of 2019 in Portopalo di Capo Passero.
}

\subsection{Architecture for the sea}

At once all the nets are set forth in the waves like a city, and the net has its gate-keepers and gates, and inner channels. The tuna rush in arrayed like phalanxes of men... They pour into the nets endlessly, so long as they desire and as the net can receive the throng of them. (Oppian, Halieutica 3.146).

The second-century AD poet Oppian of Cilicia describes techniques of net-fishing that are remarkably similar to contemporary practice. These ancient methods, and the accompanying architecture, were developed further during the Medieval period (Lentini, 2018).

The complete net system ('madraga') was arranged to block the tuna's path of migration, forcing it to head toward the final 'camera della morte or corpu' (13) where it was trapped. The net system consisted of two major parts. The 'pedale' stretched from the shore or a near-shore reef into the water for a distance of up to several kilometres until it connected to the chambered net structure called the 'isula'. Running approximately perpendicular to the isula, the pedale was held in position by cables ('summi'), anchored on the surface to buoys and fixed on the bottom by tuff ashlars ('rusazzi') and iron anchors on either side of the net wall to counteract the currents. The pedale contained several segments ('toccu vasciu', 'toccu mediu', 'toccu avutu'), as well as a three-sided chamber ('pirali or campili') facing the isula. The lead nets, made from a wide mesh to reduce drag from the currents, served two key functions: they forced the tuna toward the chambers and provided supporting buttresses for the isula.

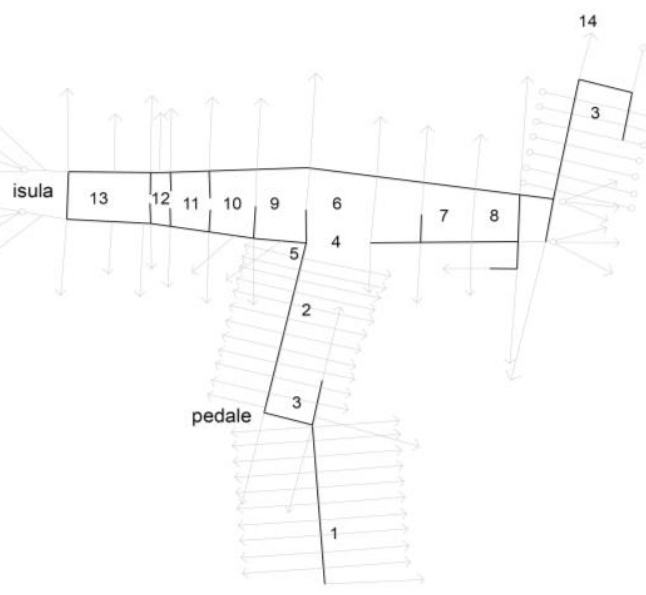

Figure 2. Diagram of the madraga: 1. toccu mediu - 2. toccu avutu - 3. campile - 4. vucca foraticu - 5. spicu - 6. foraticu -7 . ranni - 8. cammara ri livanti -9 . urdunaru -10 . bastardu -11 . cammara ri tunni or ponenti -12 . bastardedda -13 . corpu -14 . ancora di guardia.

A wide opening ('vucca foraticu') connected the pedale to the isula, also known as the 'locu ra tonnara'; this corresponds to the actual space of capture. Its height rose nearly to the water's surface, and its structure consisted of rooms ('cammari') divided by doors. The rooms lead to the 'corpu', the only chamber to have a net underneath that acts like a movable floor, forcing the tuna toward the surface when the nets were raised for slaughter. Once past the 'vucca', the tuna could not exit the isula. Instead they would cross into a series of interior chambers which varied in number depending on the size of the structure and the characteristics of the seabed. The 
last chamber needed to be on a sandy seabed, without rocks that might tear the nets, and sufficiently large, often extending for hundreds of meters ${ }^{2}$.

The isula functions like a garrison along the coast, with rope walls and interior chambers, just as Oppian describes. But the walls float with the currents, ephemeral and weightless, structured by seabed topography, sufficient only to contain the movement of the tuna and prevent their escape. The system was built from above, lowered from its central point ('cruciateddu') and held in place by weights and cables attached to buoys. The underwater structure could be viewed through the 'specchiu' and imagined through the fall of the anchors, and the movement of stone blocks with ropes. At the juncture of pedale and isula, the single element to emerge from the water was the wooden cross of the 'spicu', "covered with sacred images, guardian of the immense underwater basilica of cables and nets" (Serra, 2012). At this sacred crossroads where pedale joins isula, the tuna's free swimming trajectories transformed into forced circuits of impending death.

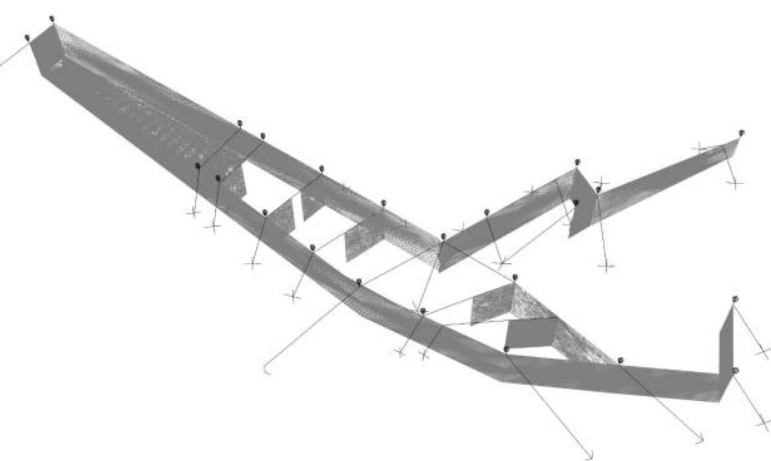

Figure 3. 3D model of a 'madraga'.

\subsection{Architecture for the land}

The structure of nets in the water continued, connected by the sea and the fishermen's boats, onto the coast, where a stone slipway ('balata') joined the sea to the cobblestones of the small harbor. Since antiquity, tuna fishing has required such landing places for the first processing of the catch, probably due to the large number and size of the tuna. One example can be found along the north side of Punta delle Formiche, in the Municipality of Pachino. A small quarry, tanks for processing, bollards, and two cylindrical cuttings that supported the timbers of a raised 'specula' for sighting tuna suggest the entire cycle of fish processing tasks took place here (Felici, 2012). Over the centuries and with the expansion of fishing to include the entire local community, the buildings expanded around the various labor tasks, borrowing their forms from the old country houses ('bagli') and fortifications along the coasts. These structures ('marfaràggi') have not followed a consistent typology, a specific architectural lexicon, or a particular construction technique, but rather developed according to the site's specific topography and natural landscape; this is very evident in features in the tonnara of Capo Passero. Here local workers

\footnotetext{
2 About the Capo Granitola tonnara the authors say: $L$ ' "isula" aveva la forma di un quadrilatero irregolare disegnato sull 'acqua da"summi", $i$ cui lati minori -"testa ri livanti" e "testa ri punenti"- misuravano, rispettivamente, 24,5 e 21 metri, mentre i lati maggiori (quelli disposti ortogonalmente alla "costa") 458,5 (lato settentrionale) e 353,5 (lato meridionale), (Serra, 2012), 24
}

used readily available materials to create wooden trusses flanked by vaulted structures, and alternating round and pointed arches, mirroring the natural topography. In some cases, as at Vendicari, these structures are equipped with towers for sighting tuna and pirates, and very often they developed around large central courtyards, as at Marzamemi.

Arranged around the courtyard were areas dedicated to various types of work: the 'appennituri' (or 'bosco') for hanging tuna, the rooms for processing meat, the ovens for cooking, near which were one or more chimneys, the salt storage, and, in more recent structures, oil storage next to installations for boiling, canning, and warehousing of finished products. In addition to these premises for actual fish processing, the marfaràggi also contained rooms for accountants, blacksmiths, and carpenters, as well as a kitchen, canteen, and other spaces that supported the worker community. In some cases, as at Marzamemi, the fishermen's houses gave shape to villages, featuring squares and alleys to pass the time, while the large buildings for sheltering boats ('trizzana') as well as cables, buoys, and nets ('camparìa') interrupted the delicate profile of the coast with a slipways ('balate') opening into the sea. Inside each marfaràggio was the church, a gathering point for the community and a link to the wooden cross of the spicu floating offshore. The saints, songs, prayers and blasphemies of land and sea are connected by this pursuit of tuna.

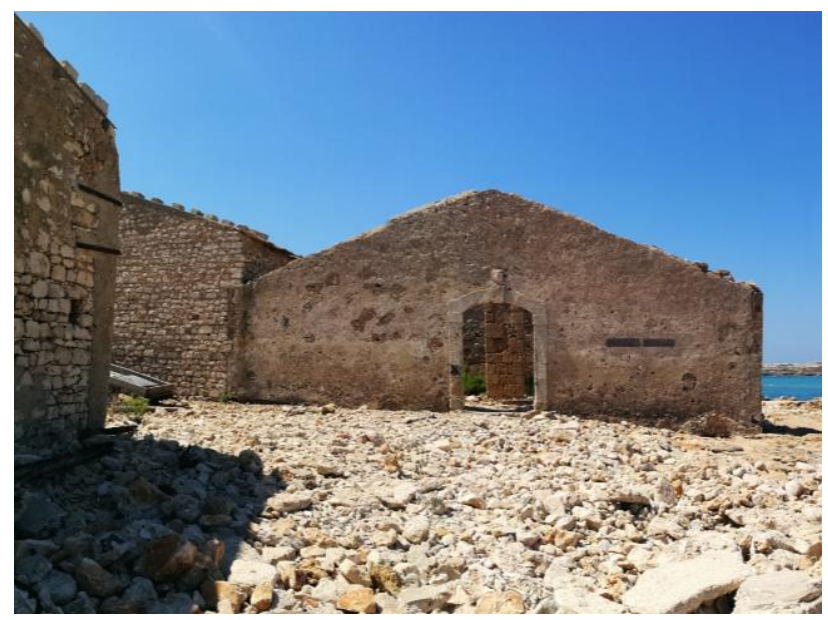

Figure 4. Buildings of the tonnara of Portopalo on Capo Passero Island.

\section{METHODOLOGY AND RESULTS}

\subsection{Starting from spaces}

Arising from the close connections of life and work, tonnare present complex spaces. Their study requires a research methodology focused on the analysis of diverse built and natural spaces and their functions and uses over time. Archaeology plays a major role in this approach, establishing links between past events or practices and particular places. To this end, a 3D digitization methodology has been developed for recording underwater sites, topographical contexts and architectural structures related to tuna fishing. By combining underwater video of ancient and historic fishing sites, landscape survey by drone photography, laser scanning of buildings and structures on land, archival documentary study, and interviews with local fishermen, we can most effectively approach the recording of this unique local architecture. 
The Integrated System for Underwater 3D Digitization (ISU3D), developed by Repola with colleagues (Repola, 2018) has been adopted for the preliminary survey activities here underwater. It includes a series of procedures in three basic phases: (A) data collection, (B) data pre-processing, and (C) data processing. The data collection phase utilizes the specially designed ScubaLibre hardware system (Repola et al., 2015 ; 2018). ScubaLibre is a stereoscopic camera system consisting of a steel bracket on which are installed two Sony HDR AS200vr cameras, positioned in their respective underwater housings $45 \mathrm{~cm}$ apart so as to have the optical axes parallel with a baseline. This first phase requires the positioning on the seabed of special scale bars to verify the correct metric scale of the model; the synchronization of videos to guarantee the extraction of pairs of simultaneous frames from the video streams; and the calibration of the cameras by recording a specific metric chessboard shot from different angles. The data pre-processing phase (B) aims to extract the exact sequence of stereoscopic image pairs intended for subsequent processing and to limit the typical effects of the degradation of the image quality in underwater environments (Bryson et al, 2012). This process entails video synchronization and color correction. Finally, the data processing procedures $(\mathrm{C})$ include the determination of the calibration parameters for each camera using MATLAB, the alignment and positioning of the images using the SFM (Structure from Motion) technique with the open source software Bundler (Snavely, 2006; Snavely, 2008), and the dense point cloud generation using SURE nFrames software developed by the Institute of Photogrammetry at the University of Stuttgart. This process utilizes a MultiView Stereo (MVS) method capable of generating a precise and dense point cloud in four steps: initialization, adjustment, matching and triangulation (Rothermel, 2012). Recording of a $25 \mathrm{~m}^{2}$, area with this system, generated a cloud of 55 million points, with a sub-centimetric level of accuracy.
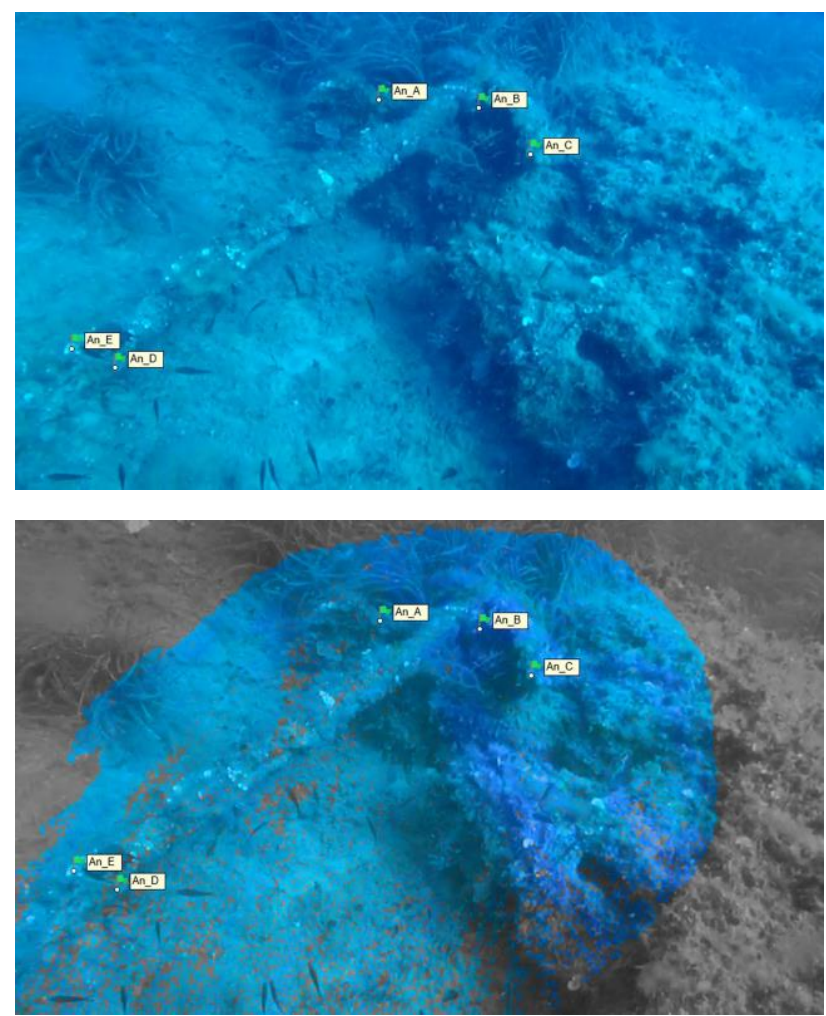

Figure 5. Images of the preliminary model of anchors off Marzamemi.
This procedure has allowed for modeling of the underwater landscape and digital experimentation with the arrangement of anchors and nets on the seabed off Marzamemi, taking into account specific marine environments, currents, topography, and the relative location of tonnare structures on land. The project plans to extend surveys to include new areas around the multiple tonnare in southeast Sicily, including to the north and south at Vendicari and Portopalo, in order to consider the impact of different marine and coastal environments on the creation of underwater architecture for the mattanza.

Subsequent to surveys on the seabed, 3D digitization activities were also carried out on land using drone photography and laser scanning, focusing on the tonnare installations at Portopalo as a first case study. A model of the island was acquired through use of an UAV, s DJI Phantom 4 Advanced Plus, equipped with a 20-megapixel 1" CMOS sensor that is preconfigured with autonomous flight instructions. A full 435 images acquired by drone were processed through the combined use of Metashape and 3DF Zephyr software, reflecting the entire Capo Passero Island and a limited portion of the coast south of the beach of Scalo Mandrie di Portopalo.

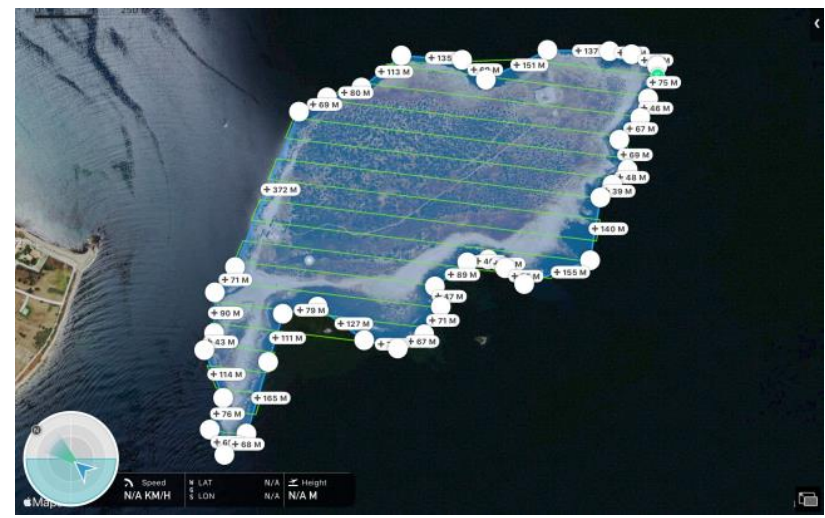

Figure 6. Drone flight path over Capo Passero Island.

Because the surveyed territory has an altimetric variation of about 20 meters as well as multiple tonnara structures, it was necessary to plan multilevel scanning grids with internal linear trajectories set to a constant altitude. Ground Sampling Distance (GSD) was set at $3.60 \mathrm{~cm} / \mathrm{px}$ with Above Ground Level (AGL) constant at $131 \mathrm{~m}$. The camera was equipped with a polarized lens to reduce reflected light from the sea's surface. The metric representation of the 3D model was made using Ground Control Points (GCP). Eight PVC GCPs, each $90 \mathrm{~cm}$ in size, were placed throughout the survey area; these were designed for contrast and visibility during aerial photography. The GCPs allow for the alignment of point clouds obtained using the software Metashape and Zephyr. Aligned point clouds were processed using Geomagic, global registration procedures, and cloud discretization for noise reduction and mesh generation. Aerial photography at Portopalo resulted in a point cloud composed of 77.7 million polygons.

These landscape survey procedures have been designed in order to connect topographic models to future digitization activities around the tonnare of Capo Passero, Marzamemi, and Vendicari, as well as the associated lagoon areas and salt pans. Such large-scale modeling allows for a comparative study of how the multiple tonnare in southeast Sicily adapted common architectural features both on land and in the sea to the varying local topographies and marine spaces. 


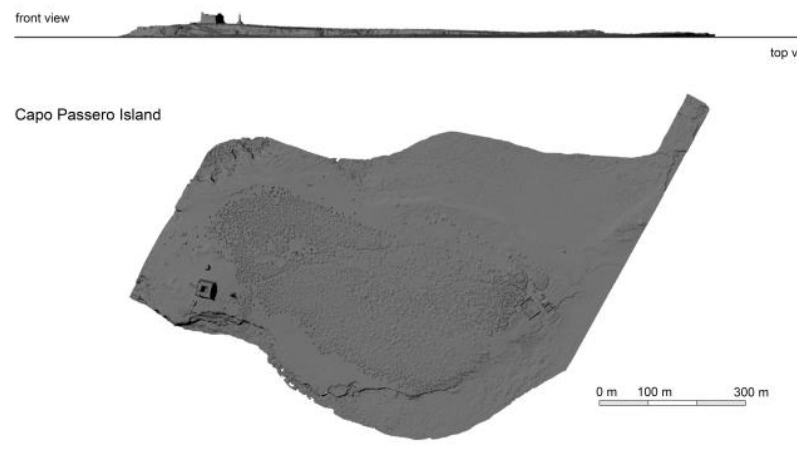

Figure 7. Polygonal topographical model of Capo Passero Island.

More detailed recording of built structures was carried out using a Faro Focus S70 phase-shift scanner. The entire tonnara of Marzamemi was documented, including the small harbor area and slipway in front: 70 scans were made for the architectural structures, while an additional 26 scans recorded the internal courtyard where two poorly preserved 'sciere' - the largest of the local tuna fishing craft - are housed. These scans provide a starting point for future efforts to preserve and reconstruct the processing area and the boats with an eye toward tourism development. Additional 3D survey documented the buildings, equipment, and nets on Capo Passero Island. Included among the recorded structures were abandoned fishing craft stored within the 'trizzana' (ship shed) on the island, one of which represents a well-preserved sciere. Three additional boats (one larger sciere and two small 'muciare') on display in Portopalo's Piazza dei Due Mari were also recorded.

For this recording of buildings and boats with the Faro scanner, two instrument settings were utilized. The first provided higher resolution with detail and equal to $1 / 2 \_4 \mathrm{x} \_3.1 \mathrm{~mm}$ at $10 \mathrm{~m} \_$scan size $20480 \times 8533 \mathrm{Pt}$; the second offered medium resolution equal to $1 / 4 \_4 \mathrm{x} \_6.1 \mathrm{~mm}$ at $10 \mathrm{~m}$ scan size $10240 \mathrm{x} 4267 \mathrm{Pt}$. Settings were defined according to the intended uses of the data. The higher resolution data preserves construction details, including plank joinery, frame placement, and other details of traditional craftsmanship; the lower resolution scans record architectural features within their topographic contexts. Point clouds acquired from the Faro scanner were pre-processed with CAM2 SCENE software for verification and alignment of multiple scans. Geomagic software was utilized for mesh production followed by NURBS generation and reverse engineering using Rhinoceros software integrated with the Grasshopper tool.

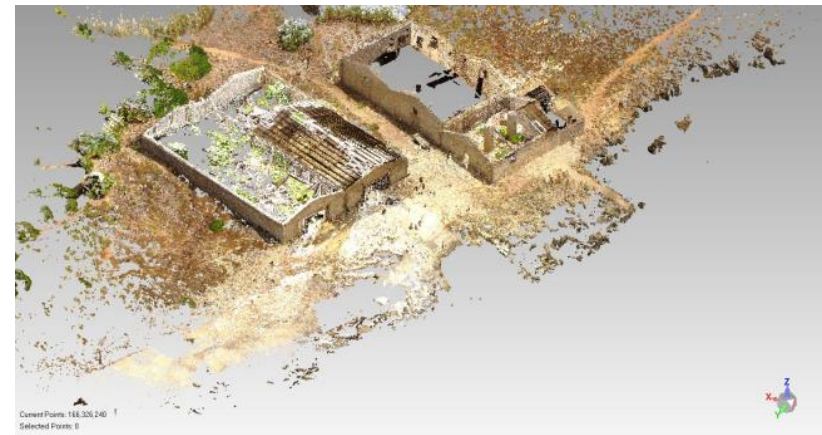

Figure 8. Point cloud model of the tonnara buildings on Capo Passero Island.

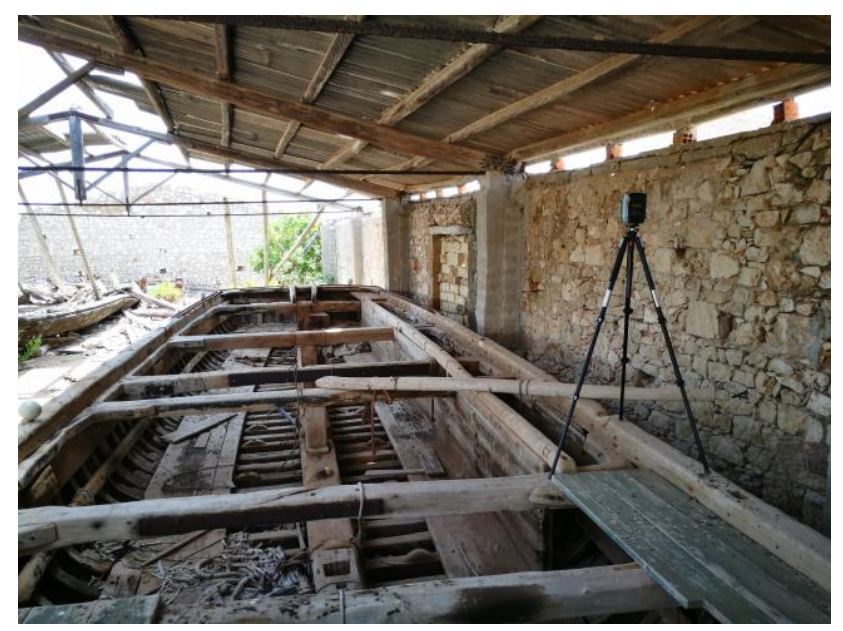

Figure 9. Survey phases of the 'sciere' within the 'trizzana' on Capo Passero Island.

While these historic vessels are, in general, unsuitable for restoration as active fishing vessels, recording of the hulls will allow their reconstruction for on-site display and the production of replica vessels that could be used to recreate the intangible heritage of the mattanza, including ship construction as well as fishing and artisanal/industrial activities. Architectural models of structures and fishing vessels will be integrated as parts of an extended survey of the entire area that will include also the submerged sites where nets were arranged, the boats that served as mobile work spaces on the water, and the structures on land used to receive and process the tuna. In each case, the local topography determines the particular architectural development of these unique spaces.

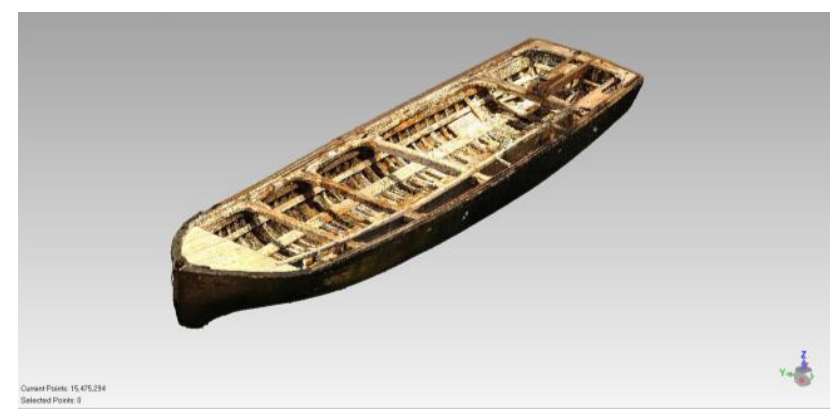

Figure 10. Point cloud of the 'sciere' in Portopalo di Capo Passero.

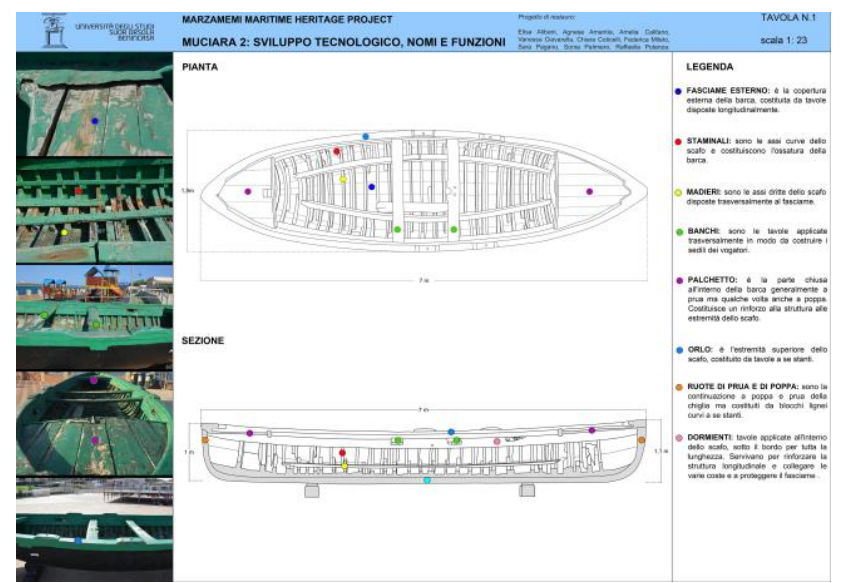

Figure 11. Graphics for the restoration project of a 'muciara' in Portopalo. 
This expansive system for representation of varied tuna fishing contexts will not only facilitate needed documentation of data and knowledge related to historic tuna fishing practices through their architecture; it will also offer unprecedented possibilities for comparative information management. The project has utilized parametric modelling procedures for both artifacts and spaces, starting from real numerical models generated by $3 \mathrm{D}$ scanning, in order to verify precisely the data sequences starting directly from spatial information, associated with information layers referencing the different fields of study.

\subsection{Technologies for dynamic heritage research}

This project as a whole has a number of aims: (1) to undertake field surveys designed to record the vernacular architecture of historic tonnare in southeast Sicily, at Portopalo di Capo Passero, Marzamemi, and Vendicari in the context of local topography and landscape; (2) to develop an advanced data management system on an interoperable GIS platform capable of integrating heterogeneous information from different sectors; and (3) to develop a data visualization system aimed at communicating and connecting different research data with varied types of stakeholders in an effort to promote new strategies for heritage development and economic opportunities in these focal areas of southeast Sicily.

The field surveys aim to achieve the 3D digitization described above with an eye toward understanding how different local topographies result in variations to standard architectural features and construction: from the structures of the tonnare, to the placement of the nets, to the numbers and forms of fishing vessels. Additional work focuses on incorporating the rich documentary records, especially the historical archives of the local tonnare, and the photographic and other materials kept in the private collections of tonnara owners, fishermen, and members of the community. Systematic archaeological surveys, both instrumental and non-instrumental, facilitate the study of contexts using a 3D GIS platform. The GIS architecture will allow the use of textual data exchange diagrams, in 2D and 3D, simultaneously with GIS and BIM (Building Information Modeling), to support spatial data segmentation. The project intends to create a single and unified management platform for heterogeneous data, accessible with multilevel logic drawing on multidisciplinary scientific fields. The first development phases of this data management system led to the production of an SQL database using SQLite with the extension of the open source SpatiaLite library (OGC-SFS) to support the integration of spatial data. Other important features of the SQLite/SpatiaLite set are the low demand for system resources that makes it compatible with mobile devices and the interoperability of data with other systems such as PostgreSQL/PostGis. The simplified interface with its closed vocabulary allows for quick entry of a first set of georeferenced and structured data to interface with the open source QGIS platform. This platform integrates well with the SQLite DB thanks to its modular architecture. This system can facilitate the connection of different areas of knowledge so as to make possible, through innovative analytical computational techniques, creation of new matrices that connect these diverse datasets.

One system for the visualization of this data management protocol entails a SCAN-to-BIM methodology, which makes it possible to progress from the $3 \mathrm{D}$ models produced by the survey, characterized by metric/geometric information, to semantic models that incorporate additional data, including traditional knowledge, construction processes, and alternate combinatory possibilities. In this regard, tests were developed to produce experimental parametric models using Grasshopper software, a visual programming language that runs within Rhino to build generative algorithms and create 3D geometry through parametric modeling based on polygonal and NURBS models of the architectural structures and spatial contexts.

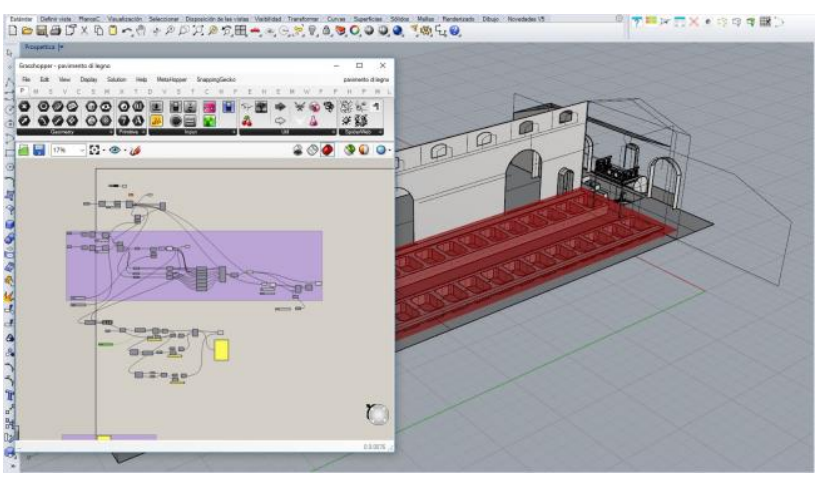

Figure 12. Parametric modeling procedures using node diagrams.

In this way the digital objects can articulate quantitative and qualitative information within an advanced analytical space according to different natural or cultural processes, temporal sequences, or architectural decisions. The transformation processes of underwater structures, archaeological sites, wrecks and anchors due to the action of humans, other living organisms, atmospheric agents, currents, and disastrous events can be combined to understand construction, destruction, and deposition. The parametric model management system works through data interpolation to sequence these connections between material objects, natural phenomena, and human activities for the unique landscape of the mattanza.

The GIS-BIM system will be connected to a data visualization program aimed at representing information according to the different practical needs and interests of individual users (e.g., children, students, local communities, tourists, governmental agencies, researchers). The Scan-toBIM methodology will structure the system to facilitate inclusive management of real and virtual data, capable of connecting and integrating within the representation procedures the large amount of information managed by the platform.

Together, these systems will support the design and management phases of a platform for immersive communication and engagement, one that functions within and outside traditional museum contexts. They provide a framework for spatialized management of video and sound content on site, and for the production of content viewable via mobile devices that support augmented reality. The systems are therefore integrated to manage the multifaceted information associated with the varied physical spaces of the tonnare. Through such innovative technologies, stakeholders can participate in the construction, use, and eventual decay processes of this locally grounded architecture and the intangible heritage traditions it supported. 


\section{CONCLUSION}

Although still in its early stages, Project ' $U$ Mari incorporates a new approach to integrated research, management, representation, and valorization of the complex and varied heritage of Mediterranean maritime life. Drawing together the three millennia and dynamic spaces that surround tuna fishing in southeast Sicily, this work seeks to forge stronger links between the on- and offshore material remains and environments, the preserved and crumbling traces of past lifeways, and the traditional knowledges and structures that intersect in this distinctive practice. Maritime heritage can thus offer a concrete link between past and present, and a new vector for understanding and preserving the social and economic forces that have shaped life along these shores.

The multifaceted vernacular architectures of the tonnarewith its structures and spaces of stone and net both in and out of the water as well as the boats that serve as mobile structures and spaces - also provide a particularly useful vantage point for incorporating heritage into a viable model for broader local development. With the transition to largescale mechanized fishing and increasing pressures on marine resources over the course of the 20th century, the age-old livelihoods tied to tuna have likewise shifted, along with the traditions and heritage wrapped up with them. Such profound transformations in the local landscape demand new approaches that balance alternative sources of economic development with the preservation of heritage along this coast and in its waters. Like many other locations across the Mediterranean, tourism provides one potential avenue of development. The multifaceted approach to the built and natural heritage of tuna fishing presented here aims to connect local and tourist communities to an intangible heritage of tuna fishing that showcases the human traditions of southeast Sicily through virtual display, heritage dive trails, artisanal tuna harvests, and sustainable culinary tourism, creating an awareness of a regional history beyond the better known Baroque architecture in the Val di Noto. With such a broad approach, heritage can form the basis for a new common language that can help facilitate engagement with local traditions, history, and livelihoods, while also supporting the continued economic development of local communities that represent the newest layer on this rich maritime landscape.

\section{ACKNOWLEDGEMENTS}

The initiatives of Project ' $U$ Mari aimed at valorizing the local heritage of tuna fishing grew out of earlier work on underwater cultural heritage in southeast Sicily. Thanks are due to Sebastiano Tusa, Adriana Fresina, Valeria Li Vigni, and Fabrizio Sgroi for their support on past and ongoing projects. We thank our local collaborators for providing not only logistical assistance and encouragement, but also a wealth of crucial information: Emilio Gregori, Luigi Marina, Francesco Bruno di Belmonte, and Gaetano Montoneri. Special thanks go to Matteo Azzaro, Sheila Matthews, Nicola Scotto di Carlo, Liz Hoffer, and the many students and colleagues who assisted in carrying out this research in the field and the lab, as well as to the organizations that provided financial and other resources: Honor Frost Foundation, Whiting Foundation, Canada Foundation for Innovation, Suor Orsola Benincasa University, Stanford University, and Brock University.

\section{REFERENCES}

Bevilacqua, V., Trotta, G., and Brunetti, A., 2017. Photogrammetric mesh and 3D points cloud recostruction: a generic algorithm optimization procedure. Communications in Computer and Information Science, 708, Springer, Cham: 65-76.

Bolognesi, C., and Garagnani, S., 2018. From a point cloud survey to a mass 3D modelling: Renaissance HBIM in Poggio a Caiano. Int. Arch. Photogramm. Remote Sens. Spatial Inf. Sci., XLII-2: 117-123.

Bryson M., Johnson-Roberson M., Pizarro O., Williams S., 2012. Colour-consistent structure-from-motion models using underwater imagery. Robotics: Science and Systems 7: 1-8.

Chiabrando, F., Lo Turco, M., Santagati, C., 2017. Digital Invasion: from Point Clouds to Historical Building Object Modeling (H-BOM) of a Unesco WHL Site. Int. Arch. Photogramm. Remote Sens. Spatial Inf. Sci., XLII-2/W3: 171-178.

Colabella S., Lancia D., Repola L., Memmolo M., Pone S., 2015. A monitoring system for wooden post-formed gridshells. International Association for Shell and Spatial Structures (IASS) Symposium 2015, Amsterdam Future Visions 17 - 20 August 2015, Amsterdam, The Netherlands, ISBN 9789053630426

Felici, E., 2012. Un impianto con thynnoskopèion per la pesca e la salagione sulla costa meridionale della Sicilia (Pachino, SR).

Herráez, J., Martínez, J.C., Coll, E.; Martín, M.T., Rodríguez, J., 2016. 3D modeling by means of videogrammetry and laser scanners for reverse engineering. Measurement, 87, 216-227.

Eliano, Oppiano e la tonnara antica. Tradizione, Tecnologia e Territorio. Bonanno Editore, Catania.

La Rocca, R., 2006. Le Cetarie: Insediamenti economico /aggregativi antesignani delle moderne tonnare. The "Cetarie": combined economic settlements standard-bearers of modern tuna plants (tonnare). Atti del $4^{\circ}$ Convegno Nazionale di Etnoarcheologia, 17-19 maggio 2006. BAR International Series 2235, Roma.

Lentini, R., 2018. Profilo storico delle tonnare siciliane in età moderna. La pesca in Campania e Sicilia. Licosia Edizioni, Ogliastro Cilento (SA).

Li Vigni, V.P., 2003. La pesca e la conservazione del tonno. organizzazione, strumenti, tecniche e funzioni. Il Lavoro del Mare, lo Stabilimento Florio. Regione Siciliana Ass. Reg. Beni Culturali, Palermo.

Li Vigni, V.P., Tusa, S., 2011. Dal Garum alle tonnare. Il rapporto tra la lavorazione del pescato nell'antichità e le tonnare moderne in Sicilia e nel Mediterraneo. Atti del $4^{\circ}$ Convegno Nazionale di Etnoarcheologia. BAR Int Ser 2235, Oxford.

Lo Curzio, M., 1992. L'architettura delle tonnare. EDAS, Messina.

Luhmann, T., Chizhova, M., Gorkovchuk, D., Hastedt, H., Chachava, N., Lekveishvili, N., 2019. Combination of terrestrial laserscanning, uav and close-range photogrammetry for $3 \mathrm{~d}$ reconstruction of complex churches in georgia. Int. Arch. Photogramm. Remote Sens. Spatial Inf. Sci., XLII-2/W11: 753-761. 
McCarthy J., Benjamin J., 2014. Multi-image photogrammetry for underwater archaeological site recording: an accessible, diver-based approach. Journal of Maritime Archaeology 9: 95114.

O'Byrne M., Pakrashi V., Schoefs F., Ghosh B., 2014. A comparison of image based 3D recovery methods for underwater inspections. EWSHM - 7th European Workshop on Structural Health Monitoring. July 2014, Nantes, France. https://hal.inria.fr/hal-01020414.

Oppian, 1928. Halieutica. Translated by A.W. Mair. W. Heinemann, London.

Pepe, C., 2006. Rotte dei tonni e luoghi delle tonnare nel Mediterraneo dalla preistoria a oggi. Quaderni della Ricerca Scientifica, Serie Beni Culturali 5, Università degli Studi Suor Orsola Benincasa, Napoli.

Prabhakar C.J., Praveen Kumar P.U., 2012. 3D surface reconstruction of underwater objects. International Jounral of $\begin{array}{llll}\text { Computer } & \text { Applications } & \text { (2012): }\end{array}$ https://arxiv.org/abs/1211.2082

Purpura, G., 1982. Pesca e stabilimenti antichi per la lavorazione del pesce in Sicilia. San Vito lo Capo (Trapani) Cala Minnola (Levanzo). Sicilia Archeologica. EPT, Trapani.

Remondino, F., 2011. Heritage Recording and 3D Modeling with Photogrammetry and 3D Scanning. Remote Sensing, 3(6), 1104-1138.

Repola L., Memmolo R., Signoretti D., 2015. Instruments and methodologies for the underwater tridimensional digitization and data musealization. Int. The International Archives of the Photogrammetry, Remote Sensing and Spatial Information Sciences, Volume XL-5/W5: 183-190.

Repola, L., Scotto di Carlo N., Signoretti D., Leidwanger J., 2018. Virtual simulation of a late antique shipwreck at Marzamemi, Sicily: Integrated processes for 3D documentation, analysis and representation of underwater archaeological data. Archaeological Prospection. John Wiley \& Sons, Ltd, pp.1-11, DOI: 10.1002/arp.1592.

Repola, L., 2018. Spazi coesistenti|Coexisting spaces. Drawing as (in) tangible representation. Gangemi Editore International, Milano.

Rothermel M., Wenzel K., Fritsch D., Haala N., 2012. SURE: Photogrammetric Surface Reconstruction from Imagery. Proceedings LC3D Workshop, Berlin, December 2012.

Sarà, R., 1998. Dal mito all'aliscafo: storie di tonni e di tonnare: migrazioni e biologia, leggende, tradizioni e socialità / Raimondo Sarà. Arti grafiche siciliane, Palermo.

Serra, G., Serra, M., 2012. Capo Granicola. Un luogo sospeso tra lo spazio e il tempo. capogranitola.it (1 December 2019).

Snavely N., Seitz S.M., Szeliski R., 2006. Photo tourism: exploring photo collections in 3D. ACM Transactions on Graphics 25(3): 835-846.

Snavely N., Seitz S.M., Szeliski R,. 2008. Modeling the world from internet photo collections. International Journal of Computer Vision 80(2): 189-210.
Sposito, C., 2007. L'architettura delle tonnare. Le tonnare, storia e architettura. Dario Flaccovio Editore, Palermo.

Tusa, S., Li Vigni, V.P., 2003. Il lavoro del mare. Lo stabilimento Florio di Favignana. Regione Siciliana, Palermo. 